\title{
HEGEMONY BY ANTONIO GRAMSCI IN THE LION KING FILM
}

\section{Jelita Dewanty Hendarsyah,* Abdul Hannan EF, Lili Awaludin}

\author{
English Literature, Faculty of Adab and Humanities, UIN Sunan Gunung Djati \\ Bandung, Indonesia \\ e-mail: jelitahendarsyah20@gmail.com
}

\begin{abstract}
In this thesis, the researcher focuses on discussing the coup in The Lion King film directed by John Favreau in 2019. This research is based on the model proposed by Antonio Gramsci's hegemony of power, this theory covers the causes of the normal practice of overthrowing power and the relationship of consent using the power structure. The purpose of this research is to find out and understand the relationship between the conflict between the main characters causing the coup d'etat represented in film literature; especially in examining the similarities in the causes of the coup d'etat from the perspective of the Hegemony of Power, the three aspects that caused the coup d'etat; Obsession, Discrimination, and Betrayal. To find out the truth, the researcher focuses on examining the hegemony of power that is applied in The Lion King Film. Hegemony is applied in the form of driving bad opinions to achieve the desired result, namely becoming a king. The results of this study indicate that there are 3 reasons for the application of the hegemony of power contained in The Lion King Film, obsession, driving bad opinion, cunning.
\end{abstract}

Keywords : Coup, research, The Lion King film, overthrowing of power, government.

\section{INTRODUCTION}


Film is one of the entertainment media for today's society and society in ancient times. According to Kridalaksana (1984:32) film is an audio-visual mass media that can reach a large audience. In the view of Dennis McQuail (1989:13) film is a means of entertainment that presents stories, events, music, drama, comedy, and other technical offerings to the general public. Films can depict or as portraits of society which are then projected onto a small screen, such as The Lion King.

Directed by John Favreau in 2019, The Lion King is the second Disney animated film to win the Golden Globe award for Best Musical and Comedy. 'Beauty and the Beast' is the first. The Lion King film is also widely liked and compared to William Shakespeare's Play Hamlet in 1599-1601. In The Lion King, the system of government that occurs is a monarchy system. Therefore, in using this monarchical system, it triggers a power struggle between a third person and someone who has the right to lead that power or known as a coup d'etat. A coup is a forced seizure of power (government). An act of reversal of power against an authorized person in an illegal way to "take over", "overthrow the power". Starting from someone's desire to seize or take over power, there was a coup between the two parties who wanted power. Coup comes from the French coup d'État or abbreviated "coup" which means to attack or blow up the country. Likewise with Scar who wants to seize the power of Prideland from Mufassa. Then, Mufasa was killed by Scar in a cunning way. Scar is Mufasa's younger brother who is also Simba's uncle. Scar wants to be king in place of Mufasa and Simba. So in an imprecise manner to seize power, Scar staged a coup d'etat closer to finding a plot where Scar would slowly approach the people of the Pride Lands, and those who didn't follow his orders would become food for the Hyenas.

"Power In This Novel No One Seeks Love by Sergius Sutanto (Antonio Gramsci Hegemony Approach)" c by Irnawati (2019). This previous study is taken by the researcher, because in her journal is related to the object of this research. In this study. The explanation of her undergraduate thesis becomes the differences between this research where her research tells about describing the hegemony of the ruling class and the elements that influence the attainment of the hegemony of the ruling class found in Sergius Sutanto's novel Ini Kali Tak Ada Yang untuk Cinta. The data in this study are texts in the form of words or sentences of the hegemony of the ruling class and elements that

influence the attainment of the hegemony of the ruling class contained in Sergius' novel, Ini Kali Nothing For Love. Sutanto. Data collection techniques in this study were reading and note-taking techniques. The similarity viewpoint of Gramsci's study of hegemony centered on the problem of the oppression of public awareness by state. The relationship between the state and the people is the entry point for hegemony power, where people's lives through colonialism by the ruler. The second previous study is an undergraduate thesis of an Analysis of the Themes of the Struggle for Power in Gajah Mada Novel: Tahta Dan Angkara Karya Langit Kresna Hariadi and Its Implications by Nursyahrifah, Adinda Putri

(2016) who analyzes. This previous study is taken by the researcher ,because in her journal is related to the object of this research.In this study. The explanation of her undergraduate thesis becomes the differences between 
this research where her research tells about the struggle for power, it is caused by a hereditary monarchy system in which case the heir to the throne is a woman who is bound by the rules of obedience to her husband even though her degree is lower and behind the husbands there are parties who want to take personal advantage of the throne so that they perform methods such as sabotage, murder, attempted murder, kidnapping, to a coup to gain power. The third previous study is an undergraduate thesis of Formations And Deep Ideological Negotiations In Tikus Shortstory by Indra Tranggono Based on Gramsci's Hegemony Perspective by Rokhmansyah, Alfian (2019) .This previous study is taken by the researcher ,because in his journal is related to the object of this research. The explanation of his undergraduate thesis becomes the differences between this research where his research tells about a analyzed about Village figures are subaltern who obeys the authorities, but as for the community who are against the authorities, depending on the perspective of each community.

\section{LITERATURE REVIEW}

The theory of hegemony is the theory put forward by Antonio Gramsci (1819-1937). The theory of hegemony is the most critical political theory of the twentieth century. Gramsci had brilliant ideas about hegemony. His theory has used a theory of social change, which was previously dominated by the thoughts of Karl Marx. Gramsci's focus is on combining analysis from Marxist economics and its emphasis on political and cultural processes. Ransome in Strinati (2007: 189) adds that Gramsci defines hegemony as a process in which the dominant class exercises power and leadership over the controlled class through a combination of power with an agreement. Hegemony can be in moral leadership, intellectual approval, and physical contact in the form of violence. Also, The theory of hegemony discusses the form of domination of power of a social class over other social classes that are considered lower classes through intellectual and moral leadership assisted by domination or oppression. Gramsci develops concepts explaining why some groups can have power and how these powerful groups build and maintain moral leadership and cultural leadership. In contrast to economic determinism, Gramsci argues that hegemony does not automatically come from those who have economic dominance from the ruling class but must be built and fought for. Gramsci was a Hegelian. Gramsci's big concept that reflects his Hegelianism is the concept of hegemony. He believes that those in the control class are hegemonic, controlling property and power and the ideology of society. Gramsci defines hegemony as cultural leadership exercised by those in power. Hegemony is different from coercion carried out by the owners of both executive and legislative powers.

Gramsci's theory of hegemony is one of the most important political theories of the twentieth century. This theory is built on the premise of the critical idea and the insufficiency of mere physical strength in socio-political control. In Gramsci's eyes, so that the ruled must not only feel they have and internalize the values and norms of the ruler, more than that, they must also approve their subordination. This is what Gramsci means by hegemony or control with consensual moral and intellectual leadership. In this context, Gramsci contrasts with hegemony, as a form of the supremacy of one or 
several groups over another, with another form of superiority that comes from domination namely power that is supported by physical force. Of course, the theory of hegemony, a novelty in the Marxist tradition. So Gramsci changed the hegemonic meaning of strategy (as according to Lenin) into a concept of power and relations of production, class, and state, became a means of understanding society to change it. He developed the idea of leadership and its implementation as a condition for obtaining state power. Hegemony is the relationship between class and other social forces.

Hegemonic class or hegemonic class group, is a class that gets the approval of power and different social classes by creating and maintaining a system of alliances through political and ideological struggles (Gramsci, 1819-1937). The concept of ideology is built by incorporating several other ideas related to it. That is why a brief definition of hegemony is never sufficient. The fact that the hegemony theory that Gramsci's theory places a lot of emphasis on centrality conventions and not on power and that ways and not on authority and consensus are "one of the main conditions for gaining power". Gramsci distinguishes two different strategies for socialism war of movement or war of maneuver and war of position. In his conception of movement warfare, Gramsci refers to the revolutionary Marxist-Leninist strategy in the struggle for socialism. The system fits well with orthodox Marxism's notion of the centrality of power in the social order. This strategy rests on the advancement of the revolutionary state to counter what it sees as violence against the bourgeoisie. The rise of the proletariat to power can be seen as a manifestation of this strategy, namely the mere change of state coercive power.

The results of the hegemonic ideas issued by Gramsci emerged when Gramsci was imprisoned, eventually resulted in a book of these thoughts and entitled Selection From The Prissons Notebook, which was written between 1929 and 1935. This book was written by Gramsci's political experiences, which supports the truth of his thinking about hegemony. For Gramsci, Hegemony means a situation in which a ruling class exercises power and leadership over subordinate classes through a combination of power and agreement. Therefore, normal practice in a Monarchy government is characterized by empathetic treatment shown to someone who should be entitled to become the next leader and try to get approval slowly as if there will be reciprocity that complements each other without any excessive power to force consent. However, the real effort ensures that the power seems to exist based on agreement (Sary, 2013:4). Hegemony is essentially the way or process of leading (influencing) others to believe in the dominant discourse within the framework determined by those in power (Sary, 2013:5). Hegemony is done to seize the throne as a ruler and make himself a leader subtly as if he has received approval from all parties (Gramsci, 1819-1937).

\section{METHOD}

According to experts, research design can be interpreted as a structured work plan in terms of the relationship between variables as a whole so that research results can provide answers to research questions. Research design is research methods, strategies to understand reality, and systematic steps to solve problems 
(Ratna, 2012). Parahoo (1997, p. 87) describes research design as a plan that describes how, when and where data is collected and analysed. The method used in this research is descriptive literature analysis method approach, namely the regular decomposition of the information that has been obtained. The understanding and explanation given is so that it can be understood well by the reader. Philosophical approach, namely the approach taken to reason systematically and compile data based on a certain point of view (in this case the point of view used is the historical point of view in learning). The researcher also uses a comparative literature approach in this study because the object that the researcher chose, namely The Lion King Film, in this object has the topic of the coup that occurred in The Lion King film.

The author observes the coup that occurred from the side of Antonio Gramsci's theory of hegemony during the Postcolonial period. In addition, the research design is a plan that describes how, when, and where data will be collected and analyzed. This research is designed as a literary criticism. Literary criticism is a term introduced by Abrams, relating to the understanding, classification, analysis, interpretation, and assessment of a literary work (Abrams, 1999). The choice of objectives The approach in this study is a form of the seriousness of the researcher in conducting research this study to analyze more closely the object. The object of this research because of the objective approach, according to Abrams, is "Objective criticism relates to literary works as something that stands free from what is often called "extrinsic" with the poet, or for the reader, or with the environmental world.

Furthermore, the researcher uses an objective approach which is an alternative that can be taken to analyze a work in determining the truth that exists in literary works

work. Abrams also says that the objective orientation, which is in principle the work of art as separate from all these external reference points, analyzes it as an independent entity formed by its parts in internal relations and is determined to judge only by intrinsic criteria. Elements in their own way become a single unit. Because the main thing

The criteria for literary criticism applied to the work is the correctness of its representation in the work of the subject it represents or must represent.

\section{FINDINGS AND DISCUSSIONS}

Conflict is one of the causes of the overthrow of power which is commonly known as a coup. In the overthrow of power, each region has its own problems. Ransome in Strinati (2007: 189) added Gramsci defines hegemony as a process in which the dominant class exercises power and leadership over the controlled class through a combination of power by agreement. Hegemony can take the form of moral leadership, intellectual approval, and physical contact in the form of violence. In addition, the theory of hegemony discusses the form of domination of power of a social class over other social classes that are considered lower classes through intellectual and moral leadership assisted by domination or oppression. Gramsci developed a concept that explains why some groups can have power in different ways to earn money and how these strong groups build and sustain moral leadership and cultural leadership. When Scar as the third person who wants to seize 
the power of Pride Land led by Mufassa, Scar does various ways to get himself to become a king. Hegemony is essentially a way or process of leading (influencing) others to believe in the dominant discourse in the framework determined by those in power (Gramsci: 1819-1937). The hegemony that occurs in The Lion King film is a normal practice in the territory of the monarchy which is characterized by empathetic treatment shown to someone who should be entitled to become the next leader and trying to get approval slowly as if there will be reciprocity that complement each other without excessive power to force consent. However, the real effort is to ensure that the power seems to exist based on agreement (Sary, 2013:4). This is done to seize the throne as a ruler and make himself a leader in a subtle way as if he has received approval from all parties. In this study, the researcher found 2 aspects of the normal practice of Antonio Gramsci's hegemony of power that was carried out by Scar against Mufassa and Simba to gain power over the Pride Lands, leading the public of Pride Lands (influencing) other people to believe in the dominant discourse to get approval.

[DATA 1], Time $=34: 23-36: 16$

[Scar comes to the forbidden area where the wild beast Hyenas gather, Scar comes there knowing that the Hyenas will also get rid of Mufassa and Simba as a king. therefore Scar conducts herding of the Hyenas, to support him to become a king of the Pride Lands and cooperate in getting rid of Mufassa and Simba.]

Queen Hyena : The Pride Lands are not yours to give

Scar : That's why we're going to kill him!

So prepare for the coup of the century;

Decades of denial is simply why I'll. Be king undisputed, Respected Saluted! (The Lion King, 2019)

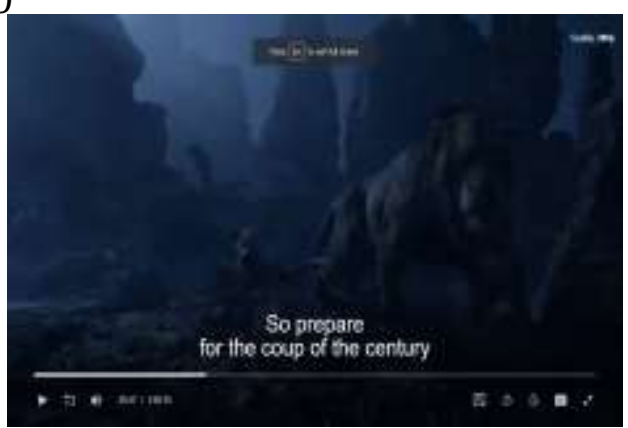

Figure 1 [ DATA 1] Scar leads the Hyenas to stage a coup ('The Lion King,2019)

At night, Scar came to the Hyena's Territory with a specific purpose. Shown in minute 34:23 when Scar came over to the Hyenas and said that he made Simba come to their Territory. "and yet i send two little cubs your way...And they comeback alive, ..Why eat one meal, When you can be feasting the rest of your life?" (Scar, 34:33, The Lion King). By influencing the Hyenas, Scar has a stronghold and comrades to fight Mufassa. Hegemony is essentially a way or process of leading (influencing) others to believe in the dominant discourse within the framework determined by those in power (Sary, 2013:5). The statement means that Scar offers interesting things for the Hyenas to get food, but Hyena insists that Pride Lands is above Mufassa's power, Then Scar 
also revealed his intention and desire to kill Mufassa, in minute 35:01 Scar says "That's why we'regoing to kill him!" Mufassa asked for help as well as cooperation for the Hyenas to get their respective benefits. Supported by Scar's statement to the Hyenas, "When i'm king, the mighty will be free to take whatever they want, Because a Hyena's belly is never full. ...Mufassa is yesterday's message!" promised that when Scar became king, the Hyenas would be satisfied in hunting for food in the Pride Lands. "People who experience decadent hegemony will do anything until they succeed in getting what they want" (Gramsci, 1901). In the end, Scar did anything to get himself to become a king, even though it hurt his brother and his nephew. Last, in minutes 36:16 The picture above is clear that Scar wants to carry out a coup against Mufassa .Scar is very obsessed with being king with a statement that he wants to be respected and appreciated. Someone obsessed with overthrowing power will crawl to formulate strategies and concepts in getting prosperity (Karl Marx: 1844).

[DATA 2] Time $=48: 56-50: 22$

[Scar announced Mufassa's death to all the inhabitants of the Pride Lands, as well as showing false compassion and at the same time leading the residents of the Pride Lands by saying that the Pride Lands must have a wise king successor.]

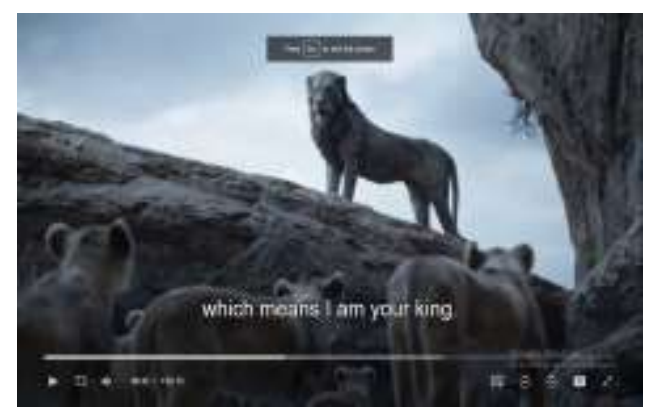

King,2019)

Figure 2 [DATA 2] how to announce mufasa's death. (The Lion

The standard practice in the territory of a hegemony of power is characterized by empathetic treatment shown to someone who should be entitled to become the next leader and to try to get approval slowly as if there will be mutual reciprocity without excessive power to force consent. However, the real effort ensures that the power seems to exist based on agreement (Gramsci: 1977). Scar finally announced that he was the right to be king to replace Mufassa. Violence is a way of domination, namely the cultivation of power from the ruling class against the oppressed class by coercion which aims to reach agreement from the controlled class and sincere acceptance of the oppressed class (Gramsci: 1912). The comfort and peace of the residents of Prideland are also threatened because anyone who doesn't follow Scar's orders will become the food of the Hyenas. Scar takes advantage of the Hyenas because, in the PrideLand area, Hyena is very well known for wild animals that are never satisfied with eating anything. Hegemony is a domination of the power of a social class over (Gramsci: 1926). In becoming a king, Scar made a statement to the residents of PrideLand. In leading the PrideLand territory, Scar made sure of it by working with the hyenas. Hegemony is essentially a way or process of leading (influencing) others to believe in the dominant discourse within the 
framework determined by those in power (Sary, 2013:5). Therefore, apply to those who do not obey Scar's orders will be given to the Hyenas as food. PrideLand residents were scared, especially the lions. Simba and his mother were very scared and didn't know what to do because they now felt like weak people who couldn't go far.

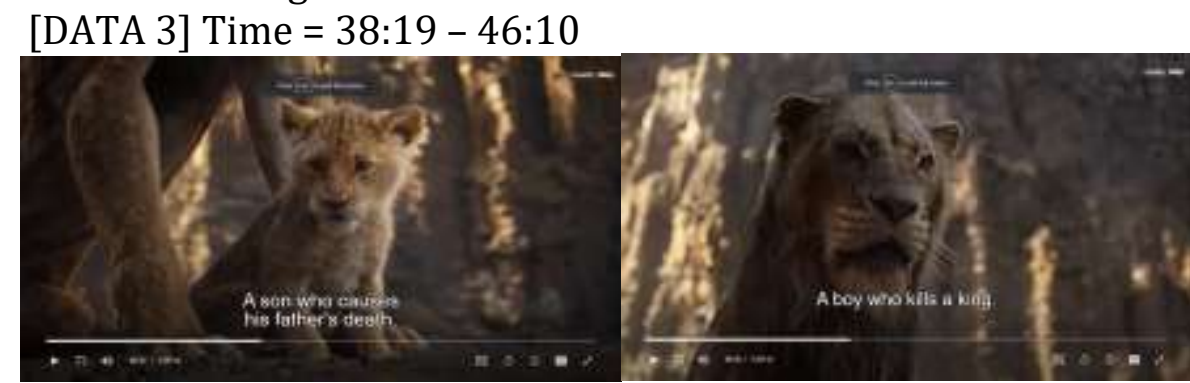

Figure 3\&4 [DATA 3] Scar Scar slandered Simba as a murderer. (The Lion King,2019)

Scar's action a coup d'etat begin in minute 38:19, shows that Scar takes Simba to a place Scar thinks is where the lion measures the power of his roar. While Simba is training and tries to roar, Scar leaves Simba alone. Where Scar has devised a devious plan with the Hyenas by trapping Mufassa. While Simba was practicing his roar, a group of black bulls attacked Simba by running from the top of the cliff. That's what Scar did to Simba and Mufasa. Scar let the Black Buffalo go down the cliff and run very fast. Scar traps Mufassa because Scar knows that Mufassa will come to save Simba. In minute 39:55, shows the Hyenas looking at the situation under the cliff and confirming what is happening to Simba. Scar also acts in trapping Mufassa; Scar goes to Mufassa and tells him that his son, Simba is in an unsafe condition. Mufassa finally ran to save his son. In minute 42:30, Mufassa managed to save Simba and immediately took him to the edge of the cliff not to be trampled by a herd of black bulls. However, after rescuing Simba, Mufassa was dragged away by the running current of the bulls, and Mufassa immediately fled. Mufassa escaped to the edge of the cliff while trying to climb up the ridge. But after Mufasa reached the edge of the cliff, Scar appeared, and Mufassa asked Scar for help, as evidenced by the scene at 43:06 to 43:16 Scar clawed at Mufassa's leg, which had reached the top and Mufassa fell off the cliff and was trampled by a herd of black bulls. when Scar scratched Mufassa's leg, Scar said, "Long Live the King!!" Scar's farewell and inner satisfaction that he finally succeeded in getting rid of the King of Pride Lands, who was his own older brother. "People who experience decadent hegemony will do anything until they succeed in getting what they want" (Gramsci; 1901). When Simba approached Mufassa's body, Simba was very sad and very devastated. Scar came to Simba, saying, "A Son who causes his father's death," as if he was not the mastermind behind Mufassa's death; Scar blamed Simba so that Simba was beaten and gave up from life. Simba ran because he felt disappointed in himself, and Scar saw Simba hit. Scar immediately told the Hyenas to chase Simba and kill him. When there is an envious nature that arises in a person, he will continue like that until what he wants is achieved. The form of reaction occurs when someone is obsessed with something that cannot be owned (Hareli \& Weiner, 2002). 
[DATA 4] Time $=1: 35: 21-1: 35: 43$
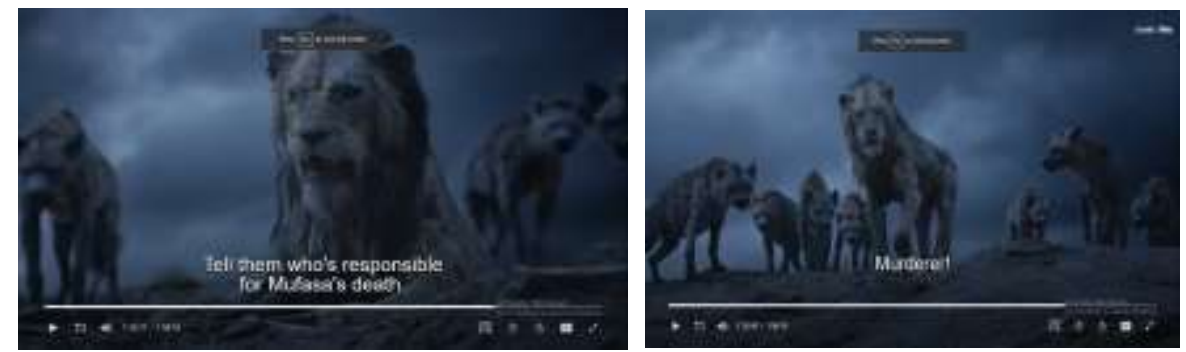

Figure 5\&6 , [DATA 4] Scar voices Simba as a killer. (The Lion King,2019)

Scar brings bad opinion to the Hyenas and residents of the Pride lands that Simba is the killer of his father, Mufassa. Scar did this as the basis for the normal practice of hegemony of power to slowly make the hyenas and residents of the pride lands negative mindset to gain approval for him to become a king.

\section{CONCLUSSION}

The researcher concludes that the takeover of power, also known as the coup d'etat, is a depiction of the betrayal of brothers and sisters in the kingdom that has been passed down from generation to generation.

monarchical system of government. In this study, the researcher finds and categorizes aspects of the depiction of a coup d'état, such as the definition of depiction of a coup d'état which is seen from the side of the kingdom that implements a monarchical government system, how the ruler regulates the people who are governed from the aspect of Antonio Gramsci's hegemony theory. In this conclusion, the researcher obtained the results of this study, namely, what? problems that led to the takeover of power or the so-called coup. And categorize the type of monarchy used in the two objects studied by the researcher. The first is a description of the problems that led to the coup, which was caused by jealousy and jealousy of the third person, namely the uncle of the main characters in The Lion King film, namely Scar. Researchers examine the depiction of power conflicts supported by using the work of Karl Marx conflict perspective theory (Marxism), about how one system reigns over another. This perspective sees society as something that is always changing, mainly because of the dynamics of power holders who keep trying maintain and improve its position. In achieving its goals, a group often has to sacrifice another group. Therefore, conflicts will always arise, and groups classified as strong always try to improve their position and maintain their dominance. In the context of maintaining social order, this perspective emphasizes the role of power. Theory of Power The theory of power states that the state is formed on the basis of power. It was the strong man who first founded the state because, by his power, he had the power to impose his will on others as Kallikles and Voltaire quipped: "The first king was a successful warrior." Scar have very strong ambitions to become rulers, therefore from the perspective of Karl Marx's conflict theory, Scar are declared strong men because they are supported by the imposition of their will, which allows them to successfully get rid of King Mufasa. Second, the depiction of the government system applied in The Lion King film. The answer to this problem 
is supported by Antonio Gramsci's theory of Hegemony written in the book Prison. The notebook states that the Hegemony that occurs in the two objects that the researcher takes using normal practice in the monarchical area is characterized by empathetic treatment shown to someone who should be entitled be the next leader and try to get the deal slowly as if there will be a complementarity without excessive force to force the deal. However, the real effort to ensure that power appears to exist is based on agreement (Gramsci: 1929-1935). The monarchy that was implemented in The Lion King film, because of the conflict of jealousy and jealousy against the previous king and the descendant king, which was in a coup because Scar had to be removed from their brothers.

\section{REFERENCES}

Abraham, M. H. (1999). A Glosary of Literary Terms. Heinle \& Heinle.

Barnet, S., Burto, W., \& Cain, W. (2008). An Introduction to Literature (Fiction, Poetry, and Drama). Pearson Longman.

Bassnett, S. (1993). Comparative Literature: A Critical Introduction. Blackwell. Blackwell, W. (2011). A Companion to Comparative Literature. Blackwell Publishing Ltd.

Brian, T. (2016). The Lion King. Walt Disney Pictures. Burbank.

Budiman, M. (2005). Tentang Sastra Bandingan. Kalam Jurnal Kebudayaan. Kebudayaan

Kalam.

Clements, R. J. (1978). Comparative Literature As Academic Discipline. The Modern Language

Association of America.

Corrigan, T., \& White, P. (2004). The film experience: An introduction. Bedford/St. Martin's.

Damono, S. D. (2005). Pegangan Penelitian Sastra Bandingan. Pusat Bahasa Departemen

Pendidikan Nasional.

Endaswara, S. (2011). Metodologi Penelitian Sastra. CAPS.

Fic, V. M. (2005). Kudeta 1 Oktober 1965 Sebuah Studi Tentang Konspirasi. Yayasan Obor Indonesia.

Garneisa, I. (2019). Lion King: Nostalgis Coup D'etat, Gambar Brilian, tapi Karakter Terasa

Hambar. tirto.id-Film.

Gramsci, A., \& H, Q. (1978). Selections from Political Writings (1921-1926). London WC1.

Harjito. (2014). Hegemoni Gramsci dalam Sastra Indonesia: Student Hijo, Nasionalisme, dan

Wacana Kolonial. UPGRIS Press.

Haryanto. (2017). Elit, Massa, dan Kekuasaan: Suatu Bahasan Pengantar. Penerbit PolGov.

Herman, V. (1995). Dramatic discourse: Dialogue as interaction in plays. Routledge.

Hikmat, M. M. (2011). Metode Penelitian: Dalam Perspektif Ilmu Komunikasi dan Sastra. 
Graha Ilmu.

Irwan, H. (2018). Hegemoni Kelas Berkuasa Terhadap Kelas Subordinat Dalam Novel Kubah Karya Ahmad Tohari (Tinjauan Hegemoni Antonio Gramsci). Universitas Negeri Makasar.

Nurrachman, D. (2017). Literary Decorum and the Function of Literature to Teach and to Semesta.

Delight. In D. Nurrachman, Intrduction to Criticism. Pustaka Aura Nurrachman, D. (2019). Critical Theory: The Contemporary Theory On Culture, Art, Language, and Literature. Pustaka Aura Semesta. 